\title{
Transmission analysis of candidate genes for nonsyndromic oral clefts in Brazilian parent-child triads with recurrence
}

\author{
Aline Lourenço da Silva ${ }^{1}$, Lucilene Arilho Ribeiro ${ }^{1,2}$, Margaret E Cooper ${ }^{3}$, Mary L Marazita ${ }^{3}$ \\ and Danilo Moretti-Ferreira ${ }^{1}$ \\ ${ }^{1}$ Universidade Estadual Paulista - UNESP, Botucatu, SP, Brazil. \\ ${ }^{2}$ Hospital de Reabilitação de Anomalias Craniofaciais, Universidade de São Paulo-USP, Bauru, SP, \\ Brazil. \\ ${ }^{3}$ Center for Craniofacial and Dental Genetics, University of Pittsburgh, Pittsburgh, PA, USA
}

\begin{abstract}
Cleft lip and/or palate (CL/P) is a major congenital defect with complex etiology, including multiple genetic and environmental factors. Approximately two thirds of the cases are not accompanied by other anomalies and are called nonsyndromic (NS). In the present study, we performed transmission distortion analysis of the MSX1-CA, TGFB3-CA and MTHFR-C677T polymorphisms in 60 parent-child triads, in which the NS-CL/P affected child had at least one affected parent. No association with genes MSX1 or TGFB3 was found, but the results were suggestive of an association of the MTHFR-C677T polymorphism with NS-CL/P.
\end{abstract}

Key words: oral clefts, cleft lip, cleft palate.

Received: February 5, 2004; Accepted: December 20, 2005.

Nonsyndromic cleft lip and/or palate (NS-CL/P) affect about $1 / 700$ livebirths, with wide variability concerning geographic distribution, ethnic background and socioeconomic status (Murray, 2002). The etiology is complex, including multiple genetic and environmental factors. The MSX1 and TGFB3 genes have been suggested as candidate genes based on animal models (Satokata and Maas, 1994; Kaartinen et al., 1995; Proetzel et al., 1995) and association studies in humans with genes MSX1, TGFB3 and MTHFR have pointed to the involvement of these genes in NS-CL/P etiology (Maestri et al., 1997; Lidral et al., 1998; Romitti et al., 1999; Mills et al., 1999; Wyszynsky and Diehl, 2000; Beaty et al., 2001). The MSX1 gene maps to chromosome 4p16. Animal models indicate that this gene plays a role in craniofacial anomalies, leading to a clefting phenotype. Van den Boogaard et al. (2000) identified a stop codon in the $M S X 1$ gene in a three-generation Dutch family with tooth agenesis and combinations of CP only and CLP, providing further evidence for the involvement of this gene in orofacial clefting. Jezewski et al. (2003) sequenced the whole $M S X 1$ gene in a large sample of NS-CL/P patients from different geographic regions, and found mutations in about $2 \%$ of the cases.

Send correspondence to Danilo Moretti-Ferreira. Serviço de Aconselhamento Genético, Departamento de Genética, IBB, Universidade Estadual Paulista - UNESP, Distrito de Rubião Júnior $s / n$, 18618-000 Botucatu, SP, Brazil. E-mail: sag@fmb. unesp.br.
The $T G F B 3$ gene maps to $14 \mathrm{q} 24$. Animal model studies demonstrated that TGFB3 plays a role in CP (Kaartinen et al., 1995; 1997; Proetzel et al., 1995; Sanford et al., 1997), and Lidral et al. (1998) showed an association between TGFB3 markers and NS-CP.

The MTHFR gene maps to $1 \mathrm{p} 36.1$, and plays a key role in the metabolism of folate by reducing methylenetrahydrofolate to 5-methyltetrahydrofolate, the primary methyl donor for methionine synthesis. The C677T nucleotide variant in the MTHFR gene results in a thermally unstable protein with reduced activity, leading to elevated plasma homocysteine levels. Considerable heterogeneity in the prevalence of the C677T polymorphism throughout the world was reported (Pepe et al., 1998).

The present work aimed to investigate if genes TGFB3, MSX1 and MTHFR-C677T are involved in the etiology of NS-CLP, by testing 60 patients, all with an affected parent. We utilized a nuclear family-based approach, to determine for each form of clefting whether these genes were in linkage disequilibrium, as measured by transmission distortion.

A total of 60 triads, each one including an affected child and at least one affected parent, were studied. Of these, 24 triads included affected mothers, and 35 triads included affected fathers. In one triad, both parents were affected, but the mother was not informative for all markers, and the triad was grouped with those of affected fathers. 
Families were ascertained at the Hospital for Rehabilitation of Craniofacial Anomalies, in Bauru, SP, Brazil. All triads were examined by a clinical geneticist to confirm that they were nonsyndromic. In addition to the information about family history and personal and medical history, parents provided blood samples. Informed consent was obtained from all adult subjects and legal guardians of underage patients. The study was performed in the years 2001 to 2003, and the participation rate of potentially eligible families was $90 \%$.

DNA was extracted from peripheral blood samples using a Puregene DNA Isolation Kit (Gentra Systems, Minneapolis, MN, USA). Subjects were tested for the markers TGFB3-CA (Lidral et al., 1997) and MSX1-CA (Padanilam et al., 1992) by means of the mutation-detection enhancement (MDE) technique. The MTHFR-C677T polymorphism was investigated by Hinf I-restriction enzyme digestion of polymerase chain reaction (PCR) products, followed by $2 \%$ agarose gel electrophoresis (Frosst et al., 1995).

Statistical tests were performed within the standard transmission disequilibrium test framework (TDT). The computer program FBAT ("Family Based Association Tests") was used for overall TDT calculations, where the biallelic TDT compares each allele to all others and the multiallelic TDT simultaneously tests the distribution of all alleles. For parent-specific TDT calculations, the S.A.G.E. TDT program was used. The entire dataset was analyzed, as well as two subsets of the data, as follows: (1) subset in which the mothers were affected; (2) subset in which the fathers were affected. In contrast to S.A.G.E., FBAT cannot separate maternal and paternal transmission calculations, but it utilizes all parental genotype information. A large portion of the data (21 families) had missing information on one or both of the parents, rendering those families uninformative for standard TDT analyses. Therefore, we also applied the likelihood ratio test (LRT) of Weinberg (1999), under the assumption that the distribution of paternal alleles is the same as the maternal. The LRT method includes the information from families with missing parental data. Since there were no significant findings, the LRT results are not reported here. Because multiple loci were evaluated in this study, a modified significance level was necessary for the interpretation of the results. We used the conservative Bonferroni adjustment for determining the appropriate significance level under multiple testing, i.e., p-values $\leq 0.017$ were considered statistically significant, and $p$-values $\leq 0.03$ were considered suggestive. Nominally significant results (i.e., p-values $\leq 0.05$ ) were also reported for thoroughness and for comparison to other published studies.

For MSX1, there were no statistically significant results considering parental transmission patterns in the entire dataset (without regard to parental affection status, FBAT), or in the data subset of triads with affected moth- ers. Some previous studies showed association or not between MSX1 variants and NS-CL/P (Lidral et al., 1997; Romitti et al., 1999; Beaty et al., 2001; Mitchell et al., 2001). Blanco et al. (2001) presented evidence of a sexdependent association between $M S X 1$ and NS-CL/P.

For $T G F B 3$, in the subset with affected fathers, the overall parental transmission distortion of allele 3 was suggestive ( $\mathrm{p}$-value $=0.03$, Table 2 ), but with only five informative triads. There was no significant transmission disequilibrium in the subset of triads with affected mothers. Several studies using this same marker in either casecontrol, family-based or both approaches combined did not find an association with NS-CL/P in populations as diverse as those in the Philippines, North America, and Japan (Lidral et al., 1997, 1998; Tanabe et al., 2000; Beaty et al., 2001). However, in a case-control study in Iowa, Romitti et al. (1999) reported an increased risk for NS-CL/P associated with the rare allele 3 of TGFB3-CA, when analyzed under a dominant model. One of us (LAR, unpublished data) found a positive association between allele 1 of the TGFB3-CA marker and NS-CL/P in Brazilian patients.

The results were suggestive of an association between NS-CL/P and the MTHFR-C677T polymorphism. When considering parental transmission without regard to parental affection status in the entire dataset, there were 13 informative triads showing significant over-transmission of the $\mathrm{C}$ allele ( $\mathrm{p}$-value $=0.02$ with S.A.G.E., and $\mathrm{p}$-value $=0.01$ with FBAT, Tables 1 and 2). In the subset with affected fathers, there was suggestive over-transmission of the $\mathrm{C}$ allele $(p=0.04$ with S.A.G.E., and 0.02 with FBAT) (Tables 1 and 2). In the two subsets with an affected parent, there was no maternal or paternal over-transmission of either the $\mathrm{C}$ or T allele (Table 1). The number of informative families was too small to draw conclusions in the "affected mother" and "affected father" subsets. It should be noted that there were no genotypic frequency differences between affected and unaffected mothers, or between affected and unaffected fathers.

The majority of affected individuals (children and parents) had the CC genotype, regardless of gender: $53.85 \%$ of the males, $46.15 \%$ of the females. There was a possible gender difference $(p=0.075)$ with females having more CC genotypes than expected (48 observed, 45 expected). Eight out of nine T carriers were males $(88.89 \%)$ and only one $(11.1 \%)$ was a female. This allele frequency difference between genders was found in another study of our group (unpublished data). The $\mathrm{T}$ allele frequency of $3.9 \%$ did not differ from the frequency in the general Brazilian population (Arruda et al., 1998). Previous studies on the association between C677T polymorphism and NSCL/P produced contradictory results (Shaw et al., 1995, 1996, 1998; Tolarova and Cervenka, 1998; Gaspar et al., 1999; Mills et al., 1999; Blanton et al., 2000, 2002; Wyszynski and Diehl, 2000; Martinelli et al., 2001; Prescott et al., 2002; van Rooij et al., 2003). 
In conclusion, our data suggest that there is an association between MTHFR, but not MSX1 or TGFB3, and NS-CL/P. The sample, however, is small and does not allow definitive conclusions. While these results are in agreement with some previous studies, the literature in general is controversial. This might reflect differences in study designs or in the investigated populations.

\section{Acknowledgments}

We thank CAPES and Fundação Lucentis for the financial support. Some of the results of this paper were obtained by using the program package S.A.G.E., which is supported by a U.S. Public Health Service Resource Grant (RR03655) from the National Center for Research Resources

\section{References}

Arruda VR, Siqueira LH, Gonçalves M, Von Zuben PM, Soares MCP, Menezes R, Anichino-Bizzacchi JM and Costa FF (1998) Prevalence of the mutation C677T in the methylenetetrahydrofolate reductase gene among distinct ethnic groups in Brazil. Am J Med Genet 78:332-335.

Beaty TH, Wang H, Hetmanski JB, Fan YT, Zeiger JS, Liang KY, Chiu YF, Vanderkolk CA, Seifert KC, Wulfsberg EA, Raymond G, Panny SR and Mcintosh I (2001) A case-control study of nonsyndromic oral clefts in Maryland. Ann Epidemiol 11:434-442.

Blanco R, Chakraborty R, Barton SA, Carreno H, Paredes M, Jara L, Palomino H and Schull WJ (2001) Evidence of a sexdependent association between the MSX1 locus and nonsyndromic cleft lip with or without cleft palate in Chilean population. Hum Biol 73:81-89.

Blanton SH, Kolle BS, Hescht JT and Mulliken JB (2000) $M T H F R$ as a risk factor in the development of familial NSCLP (Letter). Am J Med Genet 92:370-371.

Blanton SH, Kolle BS, Hescht JT and Mulliken JB (2002) MTHFR as a risk factor in the development of isolated nonsyndromic cleft lip and palate. Am J Med Genet 110:404405.

Frosst P, Blom HJ, Milos R, Goyette P, Sheppard CA, Matthews RG, Boers GHJ, Den Heijer M, Luijtmans LAJ, Van Den Heuvel L and Rozen R (1995) A candidate genetic risk factor of vascular disease: A common mutation in methylene-tetrahydrofolate reductase. Nat Genet 10:111-113.

Gaspar DA, Pavanello RC and Zatz M (1999) Role of the C677T polymorphism at the MTHFR gene on risk to nonsyndromic cleft lip with or without palate: Results from a case-control study in Brazil. Am J Med Genet 87:197-199.

Jezewski PA, Vieira AR, Nishimura C, Ludwig M, Johnson M, O’brien SE, Daack-Hirsch S, Schultz RE, Weber A, Nepomucena B, Romitti PA, Christensen K, Orioli IM, Castilla EE, Machida J, Natsume N and Murray JC (2003) Complete sequencing shows a role for MSX1 in non-syndromic cleft lip and palate. J Med Genet 40:399-407.

Juriloff DM (2002) Mapping studies in animal models. In: Wyszynski DF (ed) Cleft Lip and Palate: From Origin to Treatment. Oxford University Press, New York, pp 265282.
Kaartinen V, Voncken JW, Shuler C, Warbuton D, BU D, Heisterkamp N and Groffen J (1995) Abnormal lung development and cleft palate in mice lacking TGF-beta 3 indicates defects of epithelial-mesenchymal interaction. Nature Genet 11:415-421.

Kaartinen V, Cui XM and Heisterkamp N (1997) Transforming growth factor- $\beta 3$ regulates transdifferentiation of medial edge epithelium during palatal fusion and associated degradation of basement membrane. Dev Dyn 209:255-260.

Lidral AC, Murray JC, Buetow KH, Basart AM, Schearer H, Shiang R, Naval A, Layda E, Magee K and Magee W (1997) Studies of the candidate genes TGFB2, MSX1, TGFa, and $T G F B 3$ in the etiology of cleft lip and palate in the Philippines. Cleft Palate Craniofac J 34:1-6.

Lidral AC, Romitti PA, Basart AM, Doetschman T, Leysens NJ, Daack-Hirsch S, Semina EV, Johnson LR, Machida J, Burds A, Parnell TJ, Rubenstein JLR and Murray JC (1998). Association of MsxI and TGFB3 with nonsyndromic clefting in humans. Am J Hum Genet 63:57-68.

Maestri NE, Beaty TH, Hetmanski J, Smith EA, McIntosh I, Wyszynski DF, Liang KY, Duffy DL and Vanderkolk C (1997) Application of transmission disequilibrium tests to nonsyndromic oral clefts: Including candidate genes and enviromental exposures in the models. Am J Med Genet 73:337-344.

Martinelli M, Scapoli L and Pezzetti F (2001) C677T variant form at the MTHFR gene and CL/P: A risk factor for mothers? AM J Med Genet 98:357-360.

Mills JL, Kirke PN, Molloy AM, Burke H, Conley MR, Lee YJ, Mayne PD, Weir DG and Scott JM (1999) Methylenetetrahydrofolate reductase thermolabile variant and oral clefts. Am J Med Genet 86:71-74.

Mitchell LE, Murray JC, O'Brien S and Christensen K (2001) Evaluation of two putative susceptibility loci of oral clefts in Danish population. Am J Epidemiol 153:1007-1015.

Murray JC (2002) Gene/environment causes of cleft lip and/or palate. Clin Genet 61:248-256.

Padanilam BJ, Stadler HS, Mills KA, McLeod LB, Solursh M, Lee B, Ramirez F, Buetow KH and Murray JC (1992) Characterization of the human $H O X 7$ cDNA and identification of polymorphic markers. Hum Mol Genet 1:407-410.

Pepe G, Vanegas CO, Giusti B, Brunelli T, Marcucci R, Attanasio M, Rickardis O, Stefano GF, Prisco D, Gensini GF and Abbate R (1998) Heterogeneity in world distribution of the thermolabile C677T mutation in 5,10 methylenetetrahydrofolate reductase. Am J Hum Genet 63:917-920.

Proetzel G, Pawlowski AS, Wiles MV, Yin M, Boivin GP, Howles PN and Ding J (1995) Transforming growth factor-B3 is required for secondary palate fusion. Nature Genet 11:409-414.

Prescott NJ, Winter RM and Malcolm S (2002) Maternal MTHFR genotype contributes to the risk of non-syndromic cleft lip and palate. J Med Genet 39:368-369.

Romitti PA, Lidral AC, Munger RG, Daack-Hirsch S, Burns TL and Murray JC (1999) Candidate genes for nonsyndromic cleft lip and palate and maternal smoking and alcohol consumption: Evaluation of genotype-enviroment interactions from a population-based case-control study of orofacial clefts. Teratology 59:39-50.

Sanford LP, Ormsby I, Gittenberger-de-Groot AC, Sariola H, Friedman R, Boivin GP, Cardell EL and Doetschman T 
(1997) TGFB2 knockout mice have multiple developmental defects that are non-overlapping with other $T G F B$ knockout phenotypes. Development 124:2659-2670.

Satokata I and Maas R (1994) Msx I deficient mice exhibit cleft palate and abnormalities of craniofacial and tooth development. Nature Genet 6:348-355.

Shaw GM, Lammer EJ, Wasserman CR, O'Malley CD and Tolarova MM (1995) Risks of orofacial clefts in children born to women using multivitamins containing folic acid periconceptionally. Lancet 346:393-396.

Shaw GM, Wasserman CR, Lammer EJ, O'Malley CD, Murray JC, Basart AM and Tolarova MM (1996) Orofacial clefts, parental cigarette smoking and transforming growth factor-alpha gene variants. Am J Hum Genet 58:551-561.

Shaw GM, Wasserman CR, Murray JC and Lammer EJ (1998) Infant TGF-alpha genotype, orofacial clefts, and maternal periconceptional multivitamin use. Cleft Palate Craniofac J 35:366-370.

Tanabe A, Taketani S, Endo-Ichikawa Y, Tokunaga R, Ogawa Y and Hiramoto M (2000) Analysis of the candidate genes responsible for non-syndromic cleft lip and palate in Japanese people. Clin Sci 99:105-111.
Tolarova MM and Cervenka (1998) Classification and birth prevalence of orofacial cleft. Am J Med Genet 75:42-47.

van den Boogaard MJH, Dorland M, Beemer FA and van Amstel HKP (2000) MSX1 mutation is associated with orofacial clefting and tooth agenesis in humans. Nat Genet 24:342343.

Van Rooij IALM, Vermeij-Keers C, Kluijtmans LAJ, Ocké MC, Zielhuis GA, Goorhuid-Brouwer SM, Van Der Biezen JJ, Kuijpers-Jagtman AM and Steegers-Theunissen RPM (2003) Does interaction between maternal folate intake and the methylenetetrahydrofolate reductase polymorphisms affect the risk of cleft lip with or without cleft palate? Am J Epidemiol 157:583-591.

Weinberg CR (1999) Allowing for missing parents in genetic studies of case-parent triads. Am J Hum Genet 64:11861193.

Wyszynski DF and Diehl SR (2000) Infant C677T mutation in MTHFR, maternal periconceptional vitamin use, and risk of nonsyndromic cleft lip. Am J Med Genet 92:79-80.

\section{Internet Resources}

S.A.G.E. [1997] Statistical Analysis for Genetic Epidemiology, Release 5.1: http://genepi.cwru.edu/.

Editor: Angela M. Vianna-Morgante 